Article

\title{
Identifying the Key Information and Land Management Plans for Water Conservation under Dry Weather Conditions in the Border Areas of the Syr Darya River in Kazakhstan
}

\author{
Saltanat Yegemova ${ }^{1,2}$, Rajeev Kumar ${ }^{3}$, Jilili Abuduwaili 1,4,5,*, Long Ma 1,4,5 $\mathbb{D}$, \\ Alim Samat ${ }^{1,4,5} \mathbb{D}^{\text {, Gulnura Issanova }}{ }^{1,6,7}$, Yongxiao Ge $\mathrm{e}^{1,4,5}$, Vinod Kumar ${ }^{8} \mathbb{D}$, \\ Ali Keshavarzi ${ }^{9}$ (D) and Jesús Rodrigo-Comino ${ }^{10} \mathbb{D}$ \\ 1 Research Centre of Ecology and Environment of Central Asia (Almaty), Almaty 050060, Kazakhstan; \\ s.yegemova@gmail.com (S.Y.); malong@ms.xjb.ac.cn (L.M.); alim_smt@ms.xjb.ac.cn (A.S.); \\ agamprit@gmail.com (G.I.); geyx@live.cn (Y.G.) \\ 2 U.U. Uspanov Kazakh Research Institute of Soil Science and Agrochemistry, Almaty 050060, Kazakhstan \\ 3 Department of Environment Studies, Panjab University, Chandigarh 160014, India; answalrajeev@gmail.com \\ 4 State Key Laboratory of Desert and Oasis Ecology, Xinjiang Institute of Ecology and Geography, \\ Chinese Academy of Sciences, Str. Beijingnanlu 818, Ürümqi 830011, China \\ 5 University of Chinese Academy of Sciences, Beijing 100049, China \\ 6 Faculty of Geography and Environmental Sciences, Al-Farabi Kazakh National University, \\ Almaty 050040, Kazakhstan \\ 7 Institute of Natural Sciences and Geography, Abai Kazakh National Pedagogical University, \\ Almaty 050010, Kazakhstan \\ 8 Department of Botany, DAV University, Sarmastpur, Jalandhar 144012, Punjab, India; \\ vinodverma507@gmail.com \\ 9 Laboratory of Remote Sensing and GIS, Department of Soil Science, University of Tehran, P.O. Box 4111, \\ Karaj 31587-77871, Iran; alikeshavarzi@ut.ac.ir \\ 10 Instituto de Geomorfología y Suelos, Department of Geography, University of Málaga, 29071 Málaga, Spain; \\ rodrigo-comino@uma.es \\ * Correspondence: jilil@ms.xjb.ac.cn
}

Received: 1 October 2018; Accepted: 21 November 2018; Published: 29 November 2018 updates

\begin{abstract}
Due to an increase in poorly planned anthropogenic activities, the water quality of several Asian big rivers is highly being affected. Although the assessment of heavy metal contents is vital to develop and design sustainable water management plans, several areas in Central Asia such as Kazakhstan do not have recent studies available that evaluate this situation. One representative example of this lack of information is the Syr Darya River. Thus, this study carried out the first approach to a water quality assessment in Kazakhstan's Syr Darya River, where a massive expansion of irrigation canals, pastures in middle- and lower-reaches and an increase in industrialization and population have lowered its potential water capacity. To achieve this goal, various physicochemical parameters were analyzed for forty-three water samples along the river under dry weather conditions at $25 \mathrm{~cm}$ water depth. The obtained results were analyzed using standard methods (e.g., Multi N/C $2100 \mathrm{~S}$ analyzer or an atomic absorption spectrometer) and evaluated by multivariate techniques (cluster analysis (CA), principal component analysis (PCA), and non-metric multidimensional scaling (NDMS)) and a heavy metal pollution index (HPI). In the CA, five cluster groups were obtained. It is important to remark that the first cluster consists of the highest number of water sampling points (8). The last cluster is made up of only one point, which shows the highest difference against the other sites in our model. The NDMS also confirmed that some specific points along the river are different. Five components were extracted from the PCA: (1) COD (chemical oxygen demand), $\mathrm{Zn}, \mathrm{Cu}, \mathrm{Pb}, \mathrm{Ni}$ and $\mathrm{Mn}$; (2) $\mathrm{Cu}, \mathrm{Cd}, \mathrm{Ni}$ and $\mathrm{Co}$; (3) T (water temperature), $\mathrm{pH}$ and DO (dissolved
\end{abstract}


oxygen); (4) T and Fe; and (5) COD and OC (organic carbon). The HPI showed very high values (279.9), which were locally confirmed in some hotspots close to the Aral Sea, industrialized areas and agricultural fields. Therefore, our results demonstrate that, under dry weather conditions, surface water resources could be mismanaged in the Syr Darya River in Kazakhstan in specific areas. For the future, considering the important role that agriculture and pasture play in the Kazakh economy, we insist upon the importance of applying water quality control measures applying nature-based solutions and efficient management plans. Moreover, we confirmed the necessity to conduct further research related to sampling under other weather situations such as wet and cold conditions, different river water depths and other locations considering specific land uses, for example, grazing, mining, railways or industries.

Keywords: Kazakhstan; Syr Darya River; heavy metals; water conservation; multivariate techniques

\section{Introduction}

Water quality is a major concern for humankind due to its importance as a resource in almost all aspects of living [1,2]. The progressive human activities' development and population growth have increased the number of various xenobiotics to the water environment, which is polluting the unscathed water bodies $[3,4]$. These polluted water bodies are a great threat to aquatic flora and fauna, and human health $[5,6]$. For example, it is confirmed an increased risk of Active Pharmaceutical Ingredients (APIs) on the exposed wildlife [7]. I was found that the transfer of APIs is through the progressive tropic levels in a water-fish-osprey food chain in Delaware and Bay Rivers. Out of a total of 21 samples collected, only two samples exceed the detection limits in osprey plasma (acetaminophen and diclofenac), typically 2-3 orders of magnitude below human therapeutic concentrations (HTC). Another representative example is the research carried out by Favas et al. [8], who tested for 46 elements in four aquatic mosses (Fontinalis squamosa, Brachythecium rivulare, Platyhypnidium riparioides, and Thamnobryum alopecurum) and a freshwater red alga (Lemanea fluviatilis) from the streams of Góis mine region in Central Portugal. Despite the undetectable levels in water samples, they obtained elements $\mathrm{Zr}, \mathrm{V}, \mathrm{Cr}$, $\mathrm{Mo}, \mathrm{Ru}, \mathrm{Os}, \mathrm{Rh}, \mathrm{Ir}, \mathrm{Pt}, \mathrm{Ag}, \mathrm{Ge}$, and $\mathrm{Bi}$ in plant samples. These findings indicate that the aquatic species have a stronger tendency to accumulate xenobiotics and heavy metals [9]. The accumulated toxins have the possibility to be biomagnified in the food chain, thereby crossing their toxic thresholds and show detrimental effects $[10,11]$.

Water pollution not only threatens the biota of water bodies but also affects the sustainability of urban systems [12,13]. For instance, pollution in the Bagmati River of Kathmandu Valley is considered as a serious concern for the sustainable development of the city [14]. During the driest season of the year, the quantity of river water can reach alarming levels, defaulting the wash of pollutants, for example from agricultural fields or industries $[15,16]$. Other reasons for water pollution are the combination of climate change and an uncoordinated rapid urbanization with a lack of awareness, an insufficient adherence to municipal and industrial wastewater generation regulations and some inadequate wastewater treatment facilities [17].

In Kazakhstan, the monitoring of the surface water quality is carried out by Kazhydromet [18] under the supervision of the Ministry of Energy of the Republic of Kazakhstan. Kazhydromet classifies the total surface water into four categories: (1) normative clean; (2) moderate pollution; (3) high pollution; and (4) extremely high pollution. These categories have been decided on the basis of the threshold limit value (TLV) of harmful compounds according to Sanitary-epidemiological requirements in Kazakhstan. According to the latest reports from November 2017, Syr Darya River belongs to the second category (moderate pollution). Researchers also found the water of Syr Darya River unfit for agriculture in some places [19-21]. They concluded that it is mainly due to the fact that the discharges of waters from densely populated areas of the Ferghana Valley (Uzbekistan, Kyrgyzstan, Tajikistan), 
and from the lower reaches of the Naryn River to the Kairakkum Dam, directly fall into it. This is a continuing challenge because of the development of irrigation, and particularly of drainage and construction of big dams and water reservoirs during the last 60 years to distribute water for seed cotton and rice plantations [22,23]. However, there is a lack of scientific studies analyzing which key water physicochemical properties are directly affecting water quality or evaluating the locations of hotspots.

In semiarid areas such as Kazakhstan, the evaluation of water quality is vital for a sustainable land management and ecosystems' health. However, little is known about a precise quantification of water quality except for the government assessments. Therefore, the main aims of this research were to assess the possible influence of heavy metals and water quality parameters on Syr Darya River water quality using multivariate statistical analyses (cluster analysis, principal component analysis and non-metric multidimensional scaling) and a heavy metal pollution index (HPI) under dry weather conditions at the surface level $(25 \mathrm{~cm})$. To achieve these goals, forty-three sampling points were selected along the Syr Darya River within Kazakhstan in the summer season, as this season is safe for manual water sampling and there is no variation due to extreme rainfall events.

\section{Materials and Methods}

\subsection{Study Area}

Forty-three water samples were collected along the Syr Darya River in Kazakhstan (Figure 1). The Syr Darya River is the longest river in Central Asia and ranks second with regard to water flow, reaching about $2212 \mathrm{~km}$. Syr Darya River compromises $2790 \mathrm{~km}$ of the channel, with a basin area of almost 300,000 km². Most of the Syr Darya River flows within Kyrgyzstan (75.2\%), Uzbekistan $(15.2 \%)$, Kazakhstan (6.9\%), and Tajikistan (2.7\%). The river starts at the confluence of two water sources: Naryn and Karadarya Rivers in Uzbekistan and falls into the Aral Sea, Kazakhstan. The river is nourished mainly due to snowfalls, but it also has important rain and glacier sources [24]. There are a few inflowing streams: on the east side, Angren (Uzbekistan), Chirchik (Uzbekistan), Keles (Kazakhstan, Uzbekistan), and Arys (Kazakhstan) Rivers disembogue in the Syr Darya; and, on the west side, Karasu and Khodzhabakirgan Rivers. The mean water discharge is about $500 \mathrm{~m}^{3} \cdot \mathrm{s}^{-1}$ in the head, $703 \mathrm{~m}^{3} \cdot \mathrm{s}^{-1}$ near the confluence with Chiric and $446 \mathrm{~m}^{3} \cdot \mathrm{s}^{-1}$ in the entry [25]. Floods are usual from March-April to August-September. The highest water level is observed in winter and during the ice-drift in autumn. On the river, the main reservoirs are Shardara (Kazakhstan), Kayrakkum (Tajikistan), and Koksaray (Kazakhstan) and the main flumes are Kyzylkum (Kazakhstan), Sarkisov South Golodnostep (Uzbekistan). In addition, two hydroelectric power stations, Shardara (Kazakhstan) and Farkhad (Uzbekistan and Tajikistan), are situated on Syr Darya River. Since the middle of the last century, Syr Darya water is used for agricultural needs [22]. In this regard, the same authors confirmed a volume of runoff in the entry has decreased from $400 \mathrm{~m}^{3} \cdot \mathrm{s}^{-1}$ to $30 \mathrm{~m}^{3} \cdot \mathrm{s}^{-1}$. Nearly 700 flumes derive water from the river to fields and manufacturing plants. The main cities situated close to the Syr Darya River are Kyzylorda (Kazakhstan), Khudzhand (Tajikistan), Turkestan (Kazakhstan) and Baikonur (Kazakhstan). 


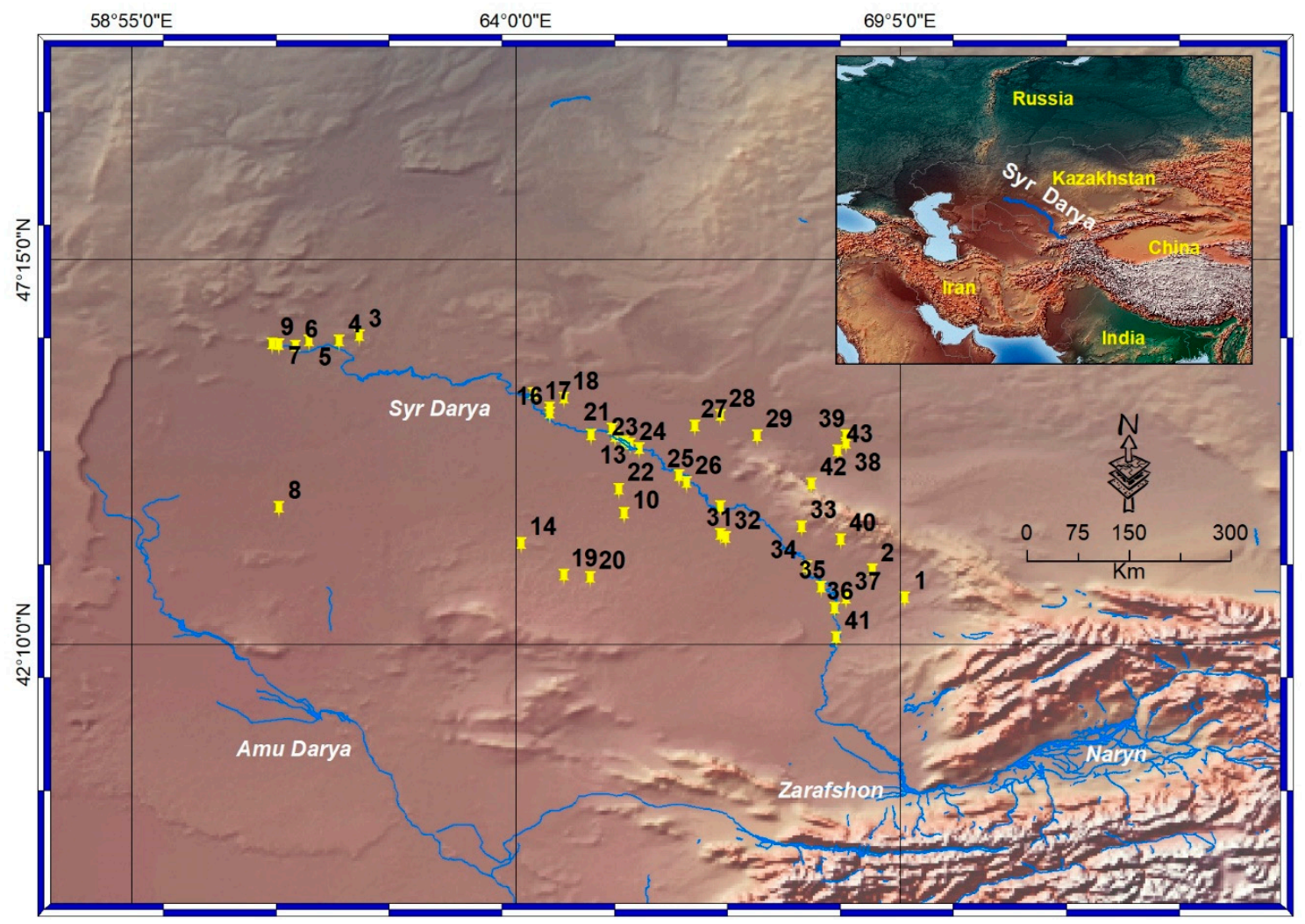

Figure 1. Study area and the location of the water samples (numbers close to the yellow pin). Source of the image: http:/ / www.naturalearthdata.com.

\subsection{Water Sampling}

The water samples were collected in the Kazakhstan part of the Syr Darya River during four days of field campaign from 7 June 2017 to 10 June 2017. All water samples were sampled in the surface water $(25 \mathrm{~cm})$ of the Syr Darya River. The data at that depth might not be representative of the total water column due to the high variability of the physical and chemical properties $[26,27]$ but we consider this depth enough for a first assessment of the surface area. They were collected under sunny weather conditions to eliminate the influence of humidity from rain, which would also affect to the physicochemical composition of water samples. As we mentioned, this is logically not representative of all weather conditions. Samples taken to assess temporal evolution due to different weather types should include several 24-h sampling campaigns as done by Shrestha et al. [28]. However, we state that such samples are difficult to obtain unless logistical issues are overcome or automatic samplers are placed, as highlighted by other works (e.g., [29]). We stored the water samples on an ISO 5667-1, 2, 3 NEQ. Selected environmental parameters such as water temperature $(\mathrm{T}), \mathrm{pH}$, electrical conductivity (EC) and dissolved oxygen (DO) were obtained in situ using a Hydrolab 5 sensor (OTT Hydromet, Loveland, CO, USA). The sensors were calibrated before sampling.

Water samples were transported in a refrigerator using an icebox to be able to analyze samples for chemical oxygen demand (COD) and organic carbon (OC) in the laboratory. In the laboratory, water samples were divided into three groups, because different chemical indicators require special analysis. For the COD and OC, the forty-three water samples were collected with no air bubbles and moved directly into a plastic vessel by adding $5 \mathrm{~mL}$ of special solution (Table 1) for conservation during transportation. COD and OC analyses were implemented after 2 days and were stored at $-12{ }^{\circ} \mathrm{C}$. The samples before analyses (one week) were stored at $-9{ }^{\circ} \mathrm{C}$ in a special refrigerator. The methods adopted for the analyses of various parameters are tabulated in Table 1. 
Table 1. Water parameters measured, units and method used for the analysis.

\begin{tabular}{cccccc}
\hline Parameters & Units & $\begin{array}{c}\text { Preservative } \\
\text { Used }\end{array}$ & $\begin{array}{c}\text { Sampling } \\
\text { Volume }\end{array}$ & $\begin{array}{c}\text { Place of } \\
\text { Determination }\end{array}$ & $\begin{array}{c}\text { Analytical } \\
\text { Method }\end{array}$ \\
\hline $\mathrm{pH}$ & $\mathrm{pH}$ unit & $\mathrm{NA}$ & $1 \mathrm{~L}$ & $\begin{array}{c}\text { Field } \\
\text { determination }\end{array}$ & $\mathrm{pH}$ meter \\
\hline $\mathrm{DO}^{*}$ & $\mathrm{mg} / \mathrm{L}$ & $\mathrm{NA}$ & $1 \mathrm{~L}$ & $\begin{array}{c}\text { Field } \\
\text { determination }\end{array}$ & Winkler's Method \\
\hline Temperature & ${ }^{\circ} \mathrm{C}$ & $\mathrm{NA}$ & $1 \mathrm{~L}$ & $\begin{array}{c}\text { Field } \\
\text { determination }\end{array}$ & Thermometer \\
\hline $\mathrm{COD}^{*}$ and $\mathrm{OC} *$ & $\mathrm{mg} / \mathrm{L}$ & $\begin{array}{c}25 \% \mathrm{H}_{2} \mathrm{SO}_{4} \\
\mathrm{pH}>2\end{array}$ & $500 \mathrm{~mL}$ & Cryopreservation & $\begin{array}{c}\text { Dichromate reflux } \\
\text { method }\end{array}$ \\
\hline Heavy metals & $\mathrm{mg} / \mathrm{L}$ & $\begin{array}{c}50 \% \mathrm{HNO}_{3} \\
\mathrm{pH}>2\end{array}$ & $125 \mathrm{~mL}$ & Cryopreservation & $\begin{array}{c}\text { Atomic absorption } \\
\text { spectrometer }\end{array}$ \\
\hline
\end{tabular}

${ }^{*} \mathrm{DO}$, dissolved oxygen; COD, chemical oxygen demand; OC, organic carbon.

\subsection{Laboratory Analysis Procedures}

All samples were prepared in triplicate in the laboratory (Figure 2). Organic carbon was estimated using a Multi N/C 2100 S analyzer made by the Analytic Jena/Instrument Development Company (2013, Jena, Germany). Chemical oxygen consumption was determined by the state standard of the Republic of Kazakhstan (ST RK 1322-2005) corresponding to ISO 6060: 1989 MOD. The method is based on the addition of a known amount of potassium dichromate and a silver catalyst (silver sulfate) in concentrated sulfuric acid, which is heated under reflux in the presence of mercury (II) sulfate. Excess potassium dichromate is titrated with Mohr's salt solution. COD is calculated based on the amount of reduced potassium dichromate.
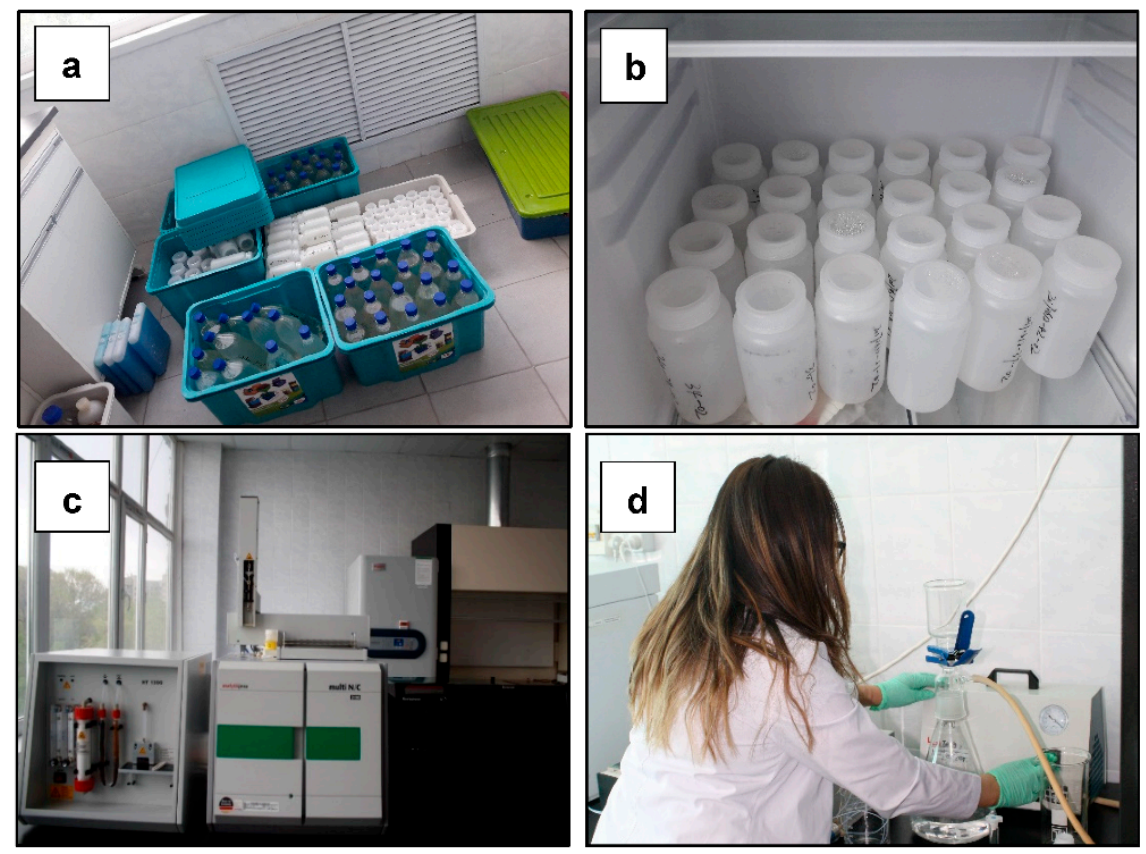

Figure 2. Working tasks in the laboratory: (a) water sampling; (b) storing water samples in the fridge; and $(\mathbf{c}, \mathbf{d})$ obtaining physicochemical water properties.

Water sample preparation for analyzing heavy metals was conducted by acidifying the samples with $6 \mathrm{~N}$ hydrochloric acids in a volume of $1 \mathrm{~mL}$ per $100 \mathrm{~mL}$ of an aqueous sample pre-filtered and evaporated at $150{ }^{\circ} \mathrm{C}$ to dryness. Then, these samples were treated with $2 \mathrm{~N}$ hydrochloric acid. After $2 \mathrm{~h}$, we analyzed the quantitative content of each heavy metal using an Atomic absorption spectrometer "ContrAA300" (2014, Jena, Germany). 


\subsection{Statistical Analysis}

\subsubsection{Descriptive Analysis and Multivariate Analyses}

First, the results of the water analysis were categorized into two different groups and depicted in box plots: some water parameters (temperature, $\mathrm{pH}$, dissolved oxygen, chemical oxygen demand, and organic carbon) and heavy metals ( $\mathrm{Zn}, \mathrm{Cu}, \mathrm{Cd}, \mathrm{Pb}, \mathrm{Fe}, \mathrm{Mn}, \mathrm{Ni}$, and $\mathrm{Co}$ ). The software used was the SigmaPlot v13 (Systat c., London, UK). After that, a multivariate analysis was performed to detect the potential causes of the current water quality status and locate the hotspots of water contamination of the river. Then, non-metric multidimensional scaling (NMDS), cluster analysis (CA), and principal component analysis (PCA) were conducted.

CA was made to find the associations of polluted and non-polluted points along the Syr Darya River. The hierarchical CA was performed according to Ward's method and Euclidean distance as a measure of similarity. The results were depicted in dendrograms using the software SPSS v23 (IBM, New York, NY, USA). Then, an NMDS was applied as an indirect gradient analysis approach to generate an ordination based on a distance or dissimilarity matrix. The software Past v3.15 (Hammer \& Harper, Oslo, Norway) was used. We consider both methods, NDMS and CA, useful and complementary to statistically demonstrate the differences among sampling areas. If we used only bar graphs or box-plots (e.g., Figures 3 and 4), the information would be very confusing and difficult to evaluate because of the elevated number of water samples. Therefore, using these methods, it would be easier to observe how some water sample points are different from the others.

Finally, PCA was mainly conducted to reduce the water physicochemical properties to a smaller set of variables. Firstly, a linear Pearson correlation $(p$-value $<0.05)$ was conducted using R software v3.0 (Statistical Computing, Vienna, Austria), to observe possible linear relationships among water properties. Then, a varimax rotation was used to determine the normalized data after examining the compatibility of datasets.

\subsubsection{Heavy Metal Pollution Index (HPI)}

The heavy metal pollution index (HPI) is an approach of ranking and evaluating the contents of each heavy metals and their collective impact on the general water quality [30]. The classification is conducted by comparing the significance of each individual heavy metal value on the water quality. It is computed as the inverse proportional of the permitted standard ( $\mathrm{Si}$ ) limit for every heavy metal, i.e., $\mathrm{Zn}, \mathrm{Cu}, \mathrm{Cd}, \mathrm{Pb}, \mathrm{Fe}, \mathrm{Mn}, \mathrm{Ni}$, and $\mathrm{Co}$. It is computed by following the next equation [31]:

$$
\mathrm{HPI}=\frac{\sum W_{i} \times Q_{i}}{\sum W_{i}}
$$

where $W_{i}$ and $Q_{i}$ are the unit weights and sub-indexes of the $\mathrm{Zn}, \mathrm{Cu}, \mathrm{Cd}, \mathrm{Pb}, \mathrm{Fe}, \mathrm{Mn}, \mathrm{Ni}$, and $\mathrm{Co}$, respectively. The value of the unit weight $\left(W_{i}\right)$ ranges from 0 to 1 . The sub-index $\left(Q_{i}\right)$ is computed by the next equation as follows:

$$
Q=\sum \frac{\left\{M_{i}(-) I_{i}\right\}}{S_{i}-I_{i}}
$$

where $M_{i}(\mu \mathrm{g} / \mathrm{L})$ represents the monitored average values of $\mathrm{Zn}, \mathrm{Cu}, \mathrm{Cd}, \mathrm{Pb}, \mathrm{Fe}, \mathrm{Mn}, \mathrm{Ni}$, and $\mathrm{Co}$, respectively. $I_{i}$ means the desirable value of drinking water standards following the protocol of the World Health Organization (WHO) [32]. $S_{i}$ is the highest permitted values of $\mathrm{Zn}, \mathrm{Cu}, \mathrm{Cd}, \mathrm{Pb}, \mathrm{Fe}, \mathrm{Mn}$, $\mathrm{Ni}$ and $\mathrm{Co}(\mu \mathrm{g} / \mathrm{L})$ and $(-)$ indicates the numerical alterations with two values ignoring the algebraic symbol. The results of HPI are ranked into three categories, namely $<19,19-38$ and $>38$, representing low, moderate and high pollution, respectively. 
Finally, the HPI was applied for each water sampling point and for the mean values along the Syr Darya River. From a geographical point of view, and for the final interpretation, this information was contrasted with the results obtained from the NDMS and CA. This assessment was vital because these results could be contrasted with a symbol map of the HPI to observe the levels of water quality along the Syr Darya River using the software ArcMap 10.5 (ESRI, Redlands, CA, USA).

\section{Results}

\subsection{Descriptive Statistics of Physicochemical Parameters, Minerals and Heavy Metals}

In Figure 3, the total average of each physicochemical water parameter per sampling point is depicted in box-plots. Water temperature shows mean value of $25.1{ }^{\circ} \mathrm{C}$, with minimum of $21.8^{\circ} \mathrm{C}$ (No. 7) and maximum of $29.5^{\circ} \mathrm{C}$ (No. 2). $\mathrm{pH}$ content obtains results from 8.2 (No. 9, 11 and 39) to 9.3 (No. 6), reaching means value of 8.3 . DO registers mean value of $8.9 \mathrm{mg} \cdot \mathrm{L}^{-1}$. The maximum value is 14.5 (No. 6) and the minimum is $7.98 \mathrm{mg} \cdot \mathrm{L}^{-1}$ (No. 33). COD amounts mean value of $19.5 \mathrm{mg} \cdot \mathrm{L}^{-1}$, recording maximum value of $63.3 \mathrm{mg} \cdot \mathrm{L}^{-1}$ (No. 32) and minimum of $4.6 \mathrm{mg} \cdot \mathrm{L}^{-1}$ (No. 17). Finally, OC values register mean value of $15.5 \mathrm{mg} \cdot \mathrm{L}^{-1}$, with maximum value of $128.2 \mathrm{mg} \cdot \mathrm{L}^{-1}$ (No. 16) and minimum of $0 \mathrm{mg} \cdot \mathrm{L}^{-1}$ in several places such as Nos. 9, 10, 12, 19, 27, 28, 40, 42 and 43.
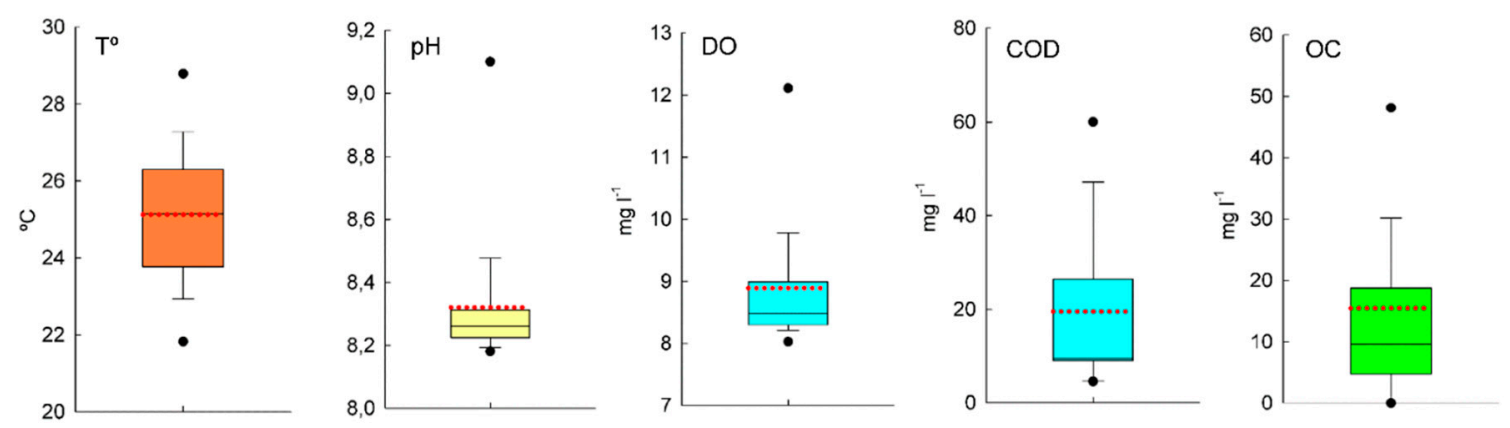

Figure 3. Physicochemical water parameters at different sample points $(n=43)$. T, Temperature; DO, dissolved oxygen; COD, chemical oxygen demand; OC, organic carbon.

In Figure 4, the content of heavy metals is also represented. Zn registers mean value of $0.08 \mathrm{mg} \cdot \mathrm{L}^{-1}$, with maximum value of 0.17 (No. 38) and minimum of $0.03 \mathrm{mg} \cdot \mathrm{L}^{-1}$ (No. 15). Cu levels show maximum of $0.03 \mathrm{mg} \cdot \mathrm{L}^{-1}$ (Nos. $1-5,32$ and 38) and minimum of 0 (No. 34). The mean value is $0.02 \mathrm{mg} \cdot \mathrm{L}^{-1}$. The mean value of $\mathrm{Pb}$ is $0.0027 \mathrm{mg} \cdot \mathrm{L}^{-1}$, registering places with null levels (Nos. 2-4, 7, 10, 17, 22, 24, 25, $31,33,36$ and $41-43$ ). The mean value of $C d$ reaches $0.008 \mathrm{mg} \cdot \mathrm{L}^{-1}$. The highest value is $0.023 \mathrm{mg} \cdot \mathrm{L}^{-1}$ (No. 9) and the lowest is $0.002 \mathrm{mg} \cdot \mathrm{L}^{-1}$ (No. 33). Mean value of $\mathrm{Ni}$ is $0.05 \mathrm{mg} \cdot \mathrm{L}^{-1}$. The maximum level of this heavy metal is $0.09 \mathrm{mg} \cdot \mathrm{L}^{-1}$ (No. 37) and the lowest is $0.02 \mathrm{mg} \cdot \mathrm{L}^{-1}$ (No. 1, 11-13). Co shows similar concentration s as Ni. The mean value is $0.05 \mathrm{mg} \cdot \mathrm{L}^{-1}$, the maximum is $0.11 \mathrm{mg} \cdot \mathrm{L}^{-1}$ (No. 12) and minimum is $0.01 \mathrm{mg} \cdot \mathrm{L}^{-1}$ (No. 34 and 39). The mean level of $\mathrm{Mn}$ is $0.14 \mathrm{mg} \cdot \mathrm{L}^{-1}$. The highest value is $0.69 \mathrm{mg} \cdot \mathrm{L}^{-1}$ (No. 32) and the lowest is $0.01 \mathrm{mg} \cdot \mathrm{L}^{-1}$ (No. 24). Finally, the mean concentration of Fe is $2.3 \mathrm{mg} \cdot \mathrm{L}^{-1}$, with minimum of $0.13 \mathrm{mg} \cdot \mathrm{L}^{-1}$ (No. 4 ) and maximum of $8.2 \mathrm{mg} \cdot \mathrm{L}^{-1}$ (No. 14). 

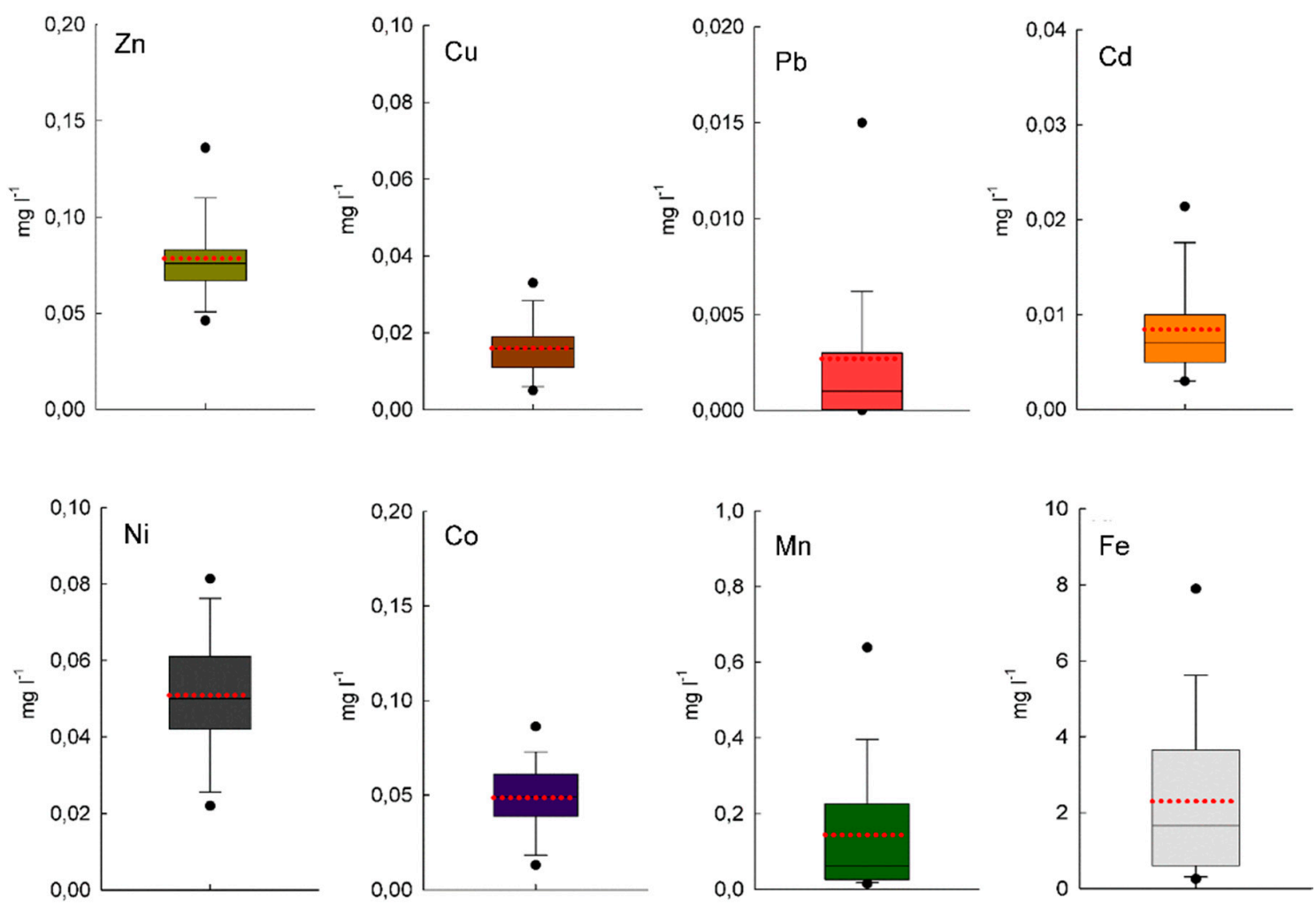

Figure 4. Heavy metal content.

\subsection{Locating the Hotspots of Water Pollution along the Syr Darya River in Kazakhstan}

\subsubsection{Non-Metric Multidimensional Scaling (NDMS) and Cluster Analysis (CA)}

Firstly, we present an NDMS scatter plot and Shepard stress plot to observe an ordination based on a distance or dissimilarity matrix (Figure 5). Figure 5 (left) with 95\% eclipse shows one sampling sites, No. 16, separated from the other ones. In addition, Nos. 2, 3, 4, 5, 8, 9 and 18 show a relative important distance from the other points. The Shepard stress plot (Figure 5, right) shows a well-correlated dataset (0.06) with a low ordination stress and a strong linear relationship $\left(\mathrm{R}^{2}=0.89\right)$, with the ordination representative of the original distances in our model. We can also confirm specific water sampling points are poorly ordered (blue arrows), despite the overall solution being acceptable.

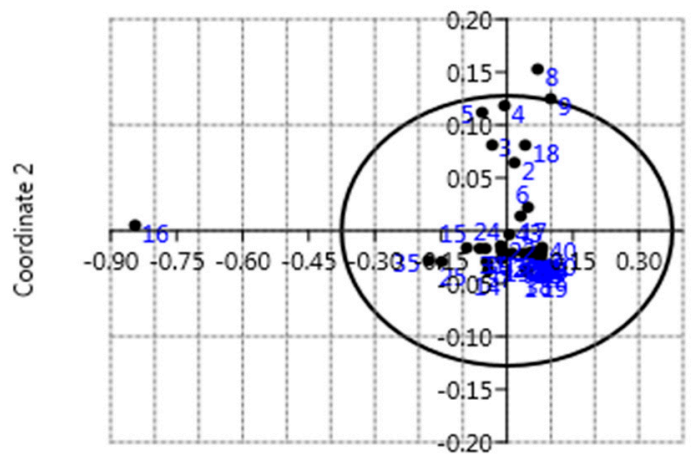

Coordinate 1

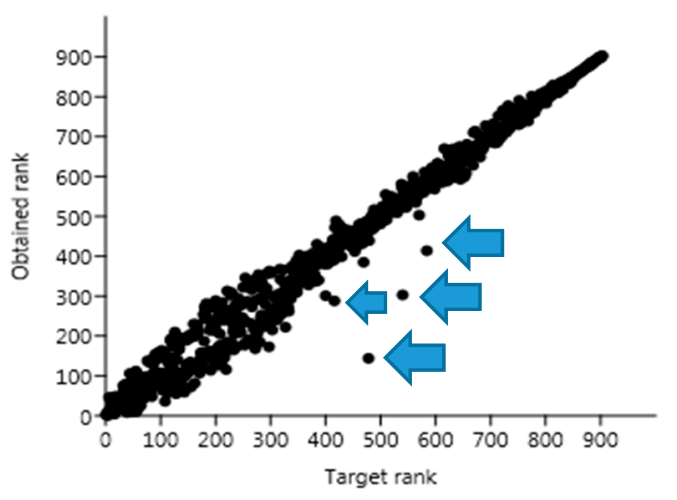

Figure 5. NMDS scatter plot (left) and Shepard 2-D plot (right) of different water sampling points along the Syr Darya River in Kazakhstan on the basis of water parameters employing Euclidean as a similarity measure. 
After that, CA was conducted and the obtained dendrogram is depicted in Figure 6. Five clusters were obtained. It is important to remark that the first cluster group consists of a higher number of water sampling points $(\mathrm{n}=8)$ with Nos. 8,9, 17, 18, 27, 34, 36 and 42 . This indicates that an elevated number of places share similar physicochemical water parameters. In addition, the second group connected to the first cluster is made up of four sampling points (Nos. 2, 6, 10 and 23). The third cluster includes six places, Nos. 7, 31 and 37, and 24-26. The fourth cluster has five sites: Nos. 3, 5, 32, 35 and 38. Finally, the last cluster consists of a unique water sampling point (No. 16), which shows the highest difference with the other sites in our model.

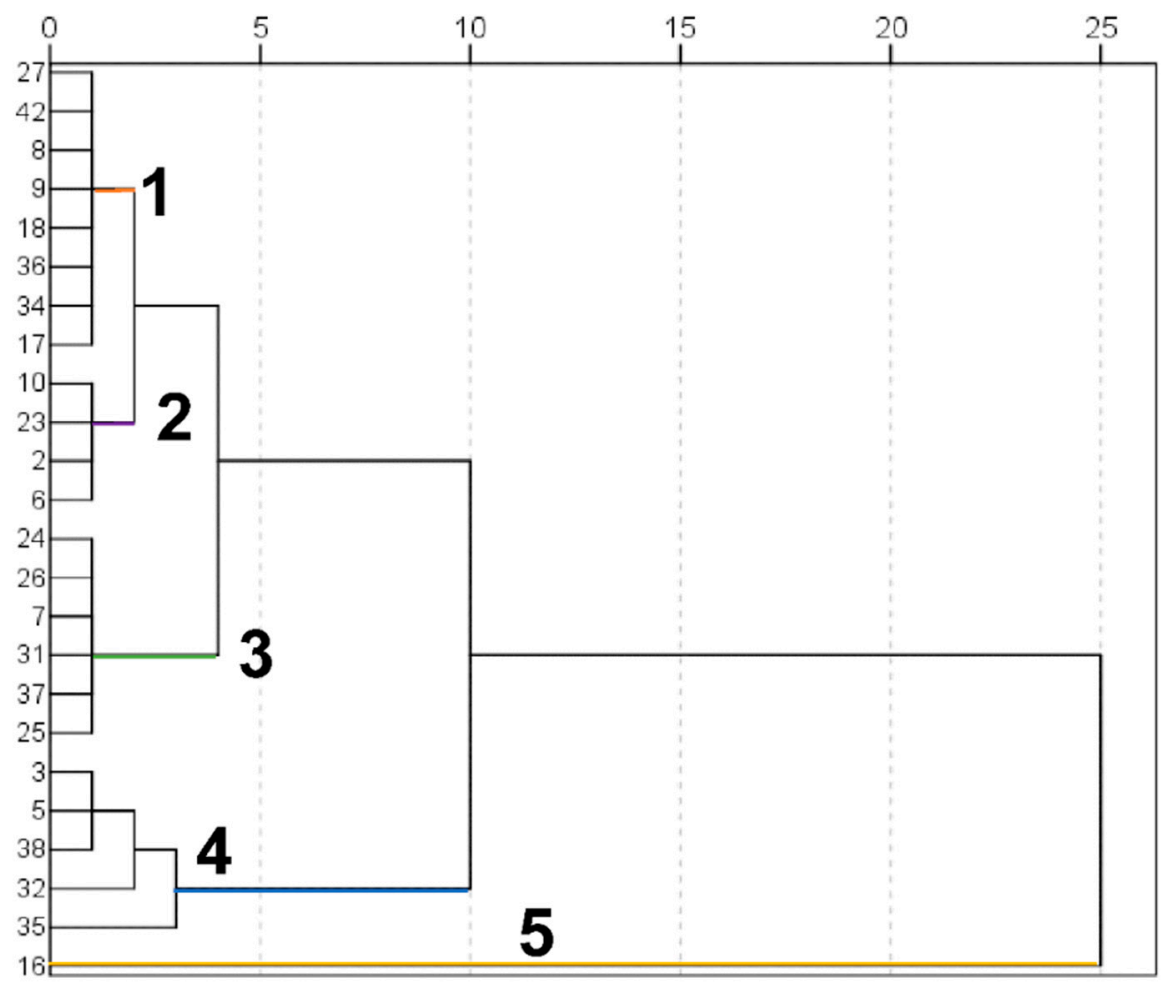

Figure 6. Dendrogram obtained from the cluster analysis.

\subsubsection{Heavy Metal Pollution Index (HPI)}

In Table 2, the mean concentration of heavy metals of the Syr Darya River and the calculation of the HPI following the WHO standard for drinking water are summarized.

Table 2. HPI calculations for the Syr Darya River following the WHO (2011) guidelines for drinking water.

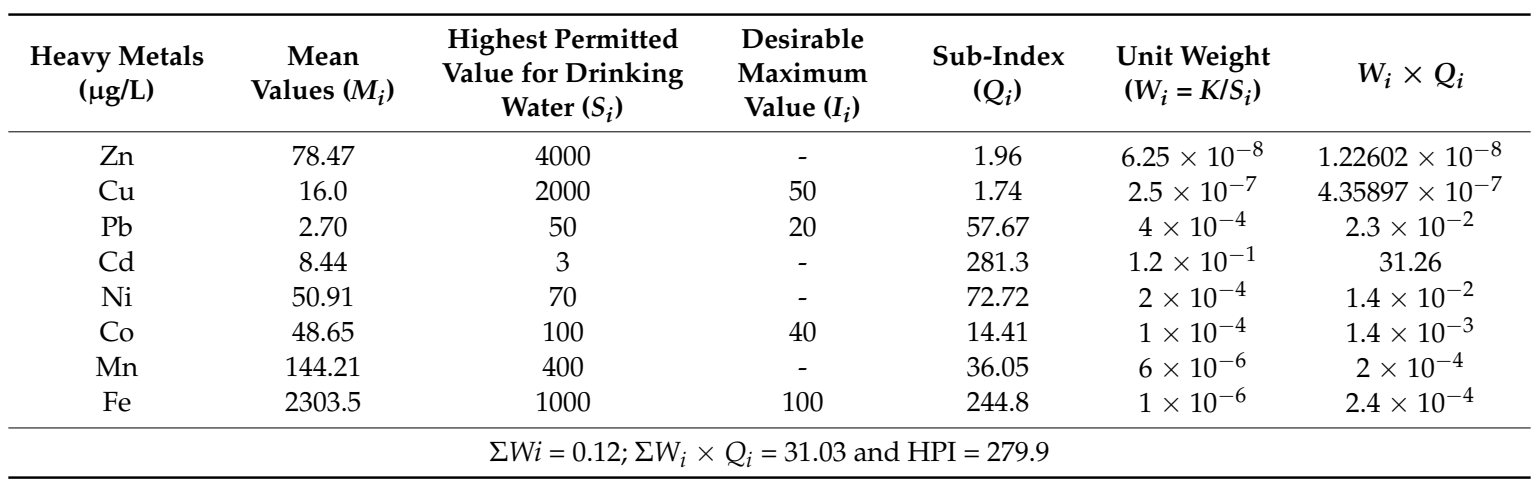


The results indicate that the Syr Darya River under dry conditions at $25 \mathrm{~cm}$ river water depth in some places in Kazakhstan has a higher heavy metal content than the critical pollution index indicates as suitable (279.9). The results infer that several places of the Syr Darya River in Kazakhstan could be seriously polluted with heavy metals. The levels of $\mathrm{Cd}, \mathrm{Co}$ and Fe are the most important factors that are increasing the levels of water contamination. On the other hand, the levels of $\mathrm{Pb}, \mathrm{Cu}, \mathrm{Zn}$, and $\mathrm{Mn}$ are still below the highest permitted value.

In Figure 7, a map of the distribution of HPI values along the Syr Darya River is represented to observe the water points with the lowest and highest pollution by heavy metals. Only No. 10 shows medium levels of water pollution, reaching 25.01 in the HPI. Nos. 22 and 26 start to overpass the limit of the index reaching values of 41.8 and 46.8, respectively. Sixteen and nineteen places are situated in the interval 50-100 and 100-150, respectively. Nos. 5, 27 and 39 are situated between 150 and 200. Finally, Nos. 2 and 3 are considered the highest polluted points, registering values of 209.6 and 237.8, respectively.

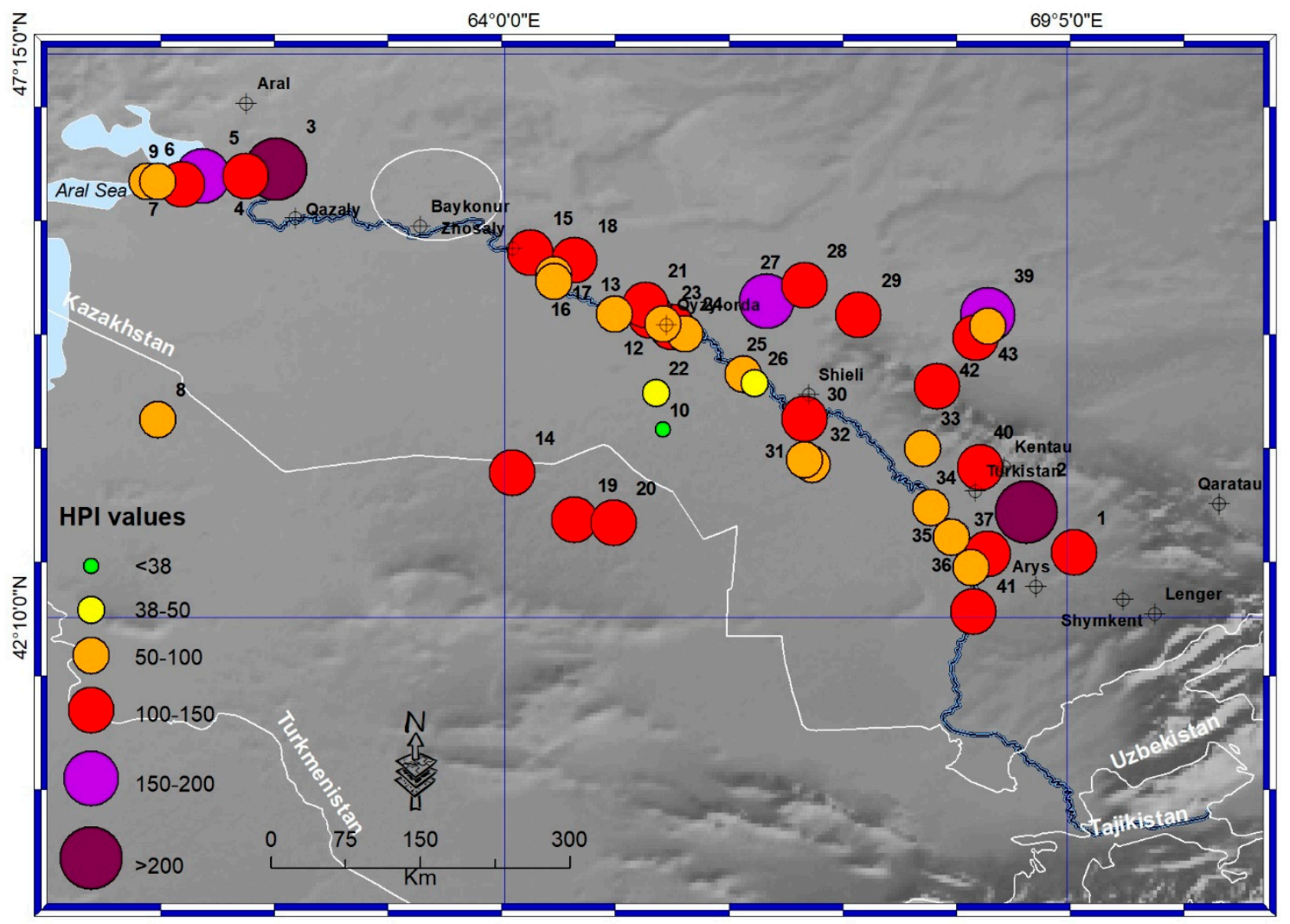

Figure 7. Map of the distribution of HPI values along the Syr Darya River.

\subsection{Key Factors Affecting the Water Quality in the Syr Darya River}

In Figure 8, the Pearson correlation coefficient is presented in the form of a matrix where the blue numbers represent the positive correlations and the red numbers the negative ones. The highest correlations are found between the heavy metals $\mathrm{Pb}$ and $\mathrm{Zn}(0.88), \mathrm{Pb}$ and $\mathrm{Mn}(0.85)$, and $\mathrm{Mn}$ and $\mathrm{Zn}$ (0.85). In addition, Fe and Mn are positively correlated (0.68). Other heavy metals with high correlations are $\mathrm{Cu}$ with $\mathrm{Cd}$ and $\mathrm{Co}$, both reaching 0.56 . On the other hand, it is important to highlight the high correlation between a physicochemical property, $\mathrm{COD}$, and the heavy metals: $\mathrm{Pb}(0.64), \mathrm{Zn}$ (0.56) and $\mathrm{Mn}(0.55)$. Finally, $\mathrm{T}$ and $\mathrm{pH}$, and $\mathrm{pH}$ and $\mathrm{DO}$ achieve a positive correlation, reaching 0.6 and 0.66 , respectively. 


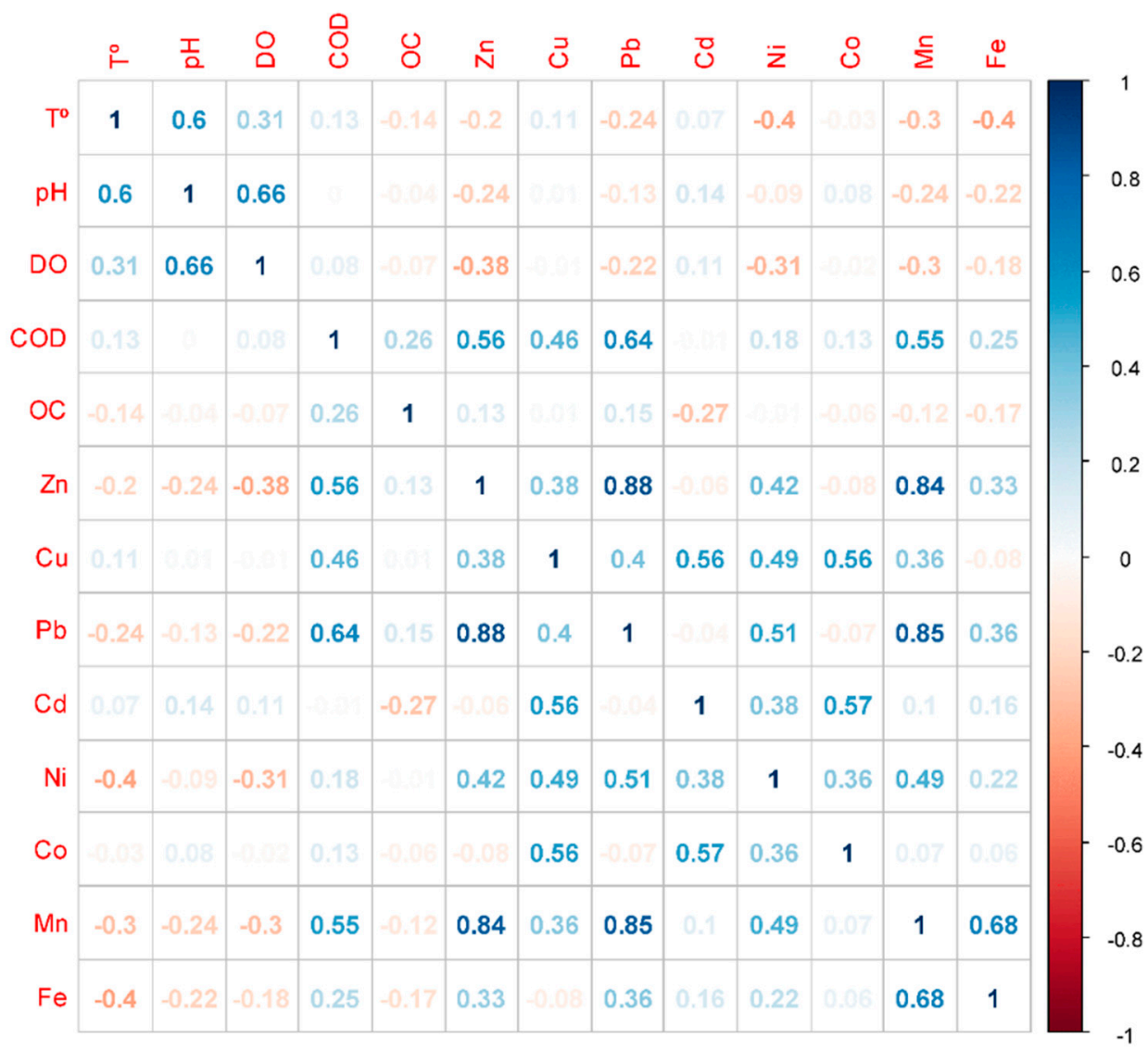

Figure 8. Pearson correlation coefficient.

After that, a PCA was conducted and the total explained variance is summarized in Table 3. Five components were obtained summarizing a final accumulated variance of $83.4 \%$.

Table 3. Total variance explained after performing a Principal Component Analysis.

\begin{tabular}{ccccccc}
\hline \multirow{2}{*}{ Components } & \multicolumn{3}{c}{ Initial Auto-Values } & \multicolumn{3}{c}{ Rotated Values } \\
\cline { 2 - 7 } & Total & Variance (\%) & Accumulated (\%) & Total & Variance (\%) & Accumulated (\%) \\
\hline 1 & 4.3 & 32.8 & 32.8 & 3.5 & 26.9 & 26.9 \\
2 & 2.4 & 18.5 & 51.3 & 2.4 & 18.1 & 45.0 \\
3 & 1.9 & 14.5 & 65.8 & 2.1 & 16.5 & 61.5 \\
4 & 1.3 & 10.2 & 76.0 & 1.4 & 11.0 & 72.5 \\
5 & 1.0 & 7.4 & 83.4 & 1.4 & 10.8 & 83.4 \\
\hline
\end{tabular}

In Table 4, the components extracted from the PCA are shown. In Component $1, \mathrm{COD}(0.71)$ and the heavy metals $\mathrm{Zn}(0.92), \mathrm{Cu}(0.44), \mathrm{Pb}(0.94), \mathrm{Ni}(0.42)$ and $\mathrm{Mn}(0.86)$ can be found. Component 2 consists of the important roles of $\mathrm{Cu}(0.76), \mathrm{Cd}(0.79), \mathrm{Ni}(0.57)$ and $\mathrm{Co}(0.88)$. Component 3 has three physicochemical parameters: $\mathrm{T}(0.64), \mathrm{pH}(0.85)$ and $\mathrm{DO}(0.85)$. Component 4 is made up of the negative coefficient of $\mathrm{T}(0.59)$ and the positive one of Fe (0.87). Finally, Component 5 is contributed by the positive relationship between COD (0.50) and OC (0.93). 
Table 4. Components extracted from the Principal Component Analysis.

\begin{tabular}{cccccc}
\hline \multirow{2}{*}{ Parameters } & \multicolumn{5}{c}{ Components } \\
\cline { 2 - 6 } & $\mathbf{1}$ & $\mathbf{2}$ & $\mathbf{3}$ & $\mathbf{4}$ & $\mathbf{5}$ \\
\hline $\mathrm{T}$ & -0.01 & -0.04 & $\mathbf{0 . 6 4}$ & $-\mathbf{0 . 5 9}$ & -0.12 \\
$\mathrm{pH}$ & -0.06 & 0.07 & $\mathbf{0 . 8 5}$ & -0.16 & -0.02 \\
$\mathrm{DO}$ & -0.20 & 0.01 & $\mathbf{0 . 8 5}$ & 0.08 & 0.01 \\
$\mathrm{COD}$ & $\mathbf{0 . 7 1}$ & 0.12 & 0.23 & 0.05 & $\mathbf{0 . 5 0}$ \\
$\mathrm{OC}$ & -0.01 & -0.09 & -0.08 & -0.04 & $\mathbf{0 . 9 3}$ \\
$\mathrm{Zn}$ & $\mathbf{0 . 9 2}$ & -0.01 & -0.24 & 0.03 & 0.02 \\
$\mathrm{Cu}$ & $\mathbf{0 . 4 4}$ & $\mathbf{0 . 7 6}$ & 0.03 & -0.28 & 0.17 \\
$\mathrm{~Pb}$ & $\mathbf{0 . 9 4}$ & 0.04 & -0.11 & 0.12 & -0.01 \\
$\mathrm{Cd}$ & -0.03 & $\mathbf{0 . 7 9}$ & 0.16 & 0.10 & -0.38 \\
$\mathrm{Ni}$ & $\mathbf{0 . 4 2}$ & $\mathbf{0 . 5 7}$ & -0.32 & 0.11 & -0.25 \\
$\mathrm{Co}$ & -0.10 & $\mathbf{0 . 8 8}$ & 0.02 & 0.08 & 0.10 \\
$\mathrm{Mn}$ & $\mathbf{0 . 8 6}$ & 0.13 & -0.15 & 0.40 & -0.15 \\
$\mathrm{Fe}$ & 0.33 & 0.03 & -0.06 & $\mathbf{0 . 8 7}$ & -0.08 \\
\hline
\end{tabular}

Black bold numbers indicate the parameters used to determine each component $(>0.40)$.

\section{Discussion}

The results of this preliminary investigation show that the levels of pollution due to the heavy metal content along the borders of the Syr Darya River are very high under dry weather conditions in several points. This situation highlights the possible incorrect water management of this basin in some areas. The impacts could be considered as very important considering that Kazakhstan comprises 25 has millions of arable land and 185 has of pasture areas [33]. In this study, we have assessed the water conservation of the Syr Darya River under two different perspectives, evaluating the water physicochemical properties and heavy metal contents in general and the specific problem points. We recognize that, for the future, we have to collect a higher number of water samples at different depths, during different seasons, to make this research more accurate and cover the elevated magnitude of the variations in each water parameter.

Our results show that water temperature during summer at the surface $(25 \mathrm{~cm}$ depth) must be considered an important key factor as a clear indicator of the water management of this river. We detected at No. 2 the highest water temperature, reaching $29.5^{\circ} \mathrm{C}$. In addition, other highly polluted areas such as Nos. 3 and 6 registered water temperatures higher than $26^{\circ} \mathrm{C}$. Although the water temperature can register to seven different configurations of fluctuation patterns [34] and high daily variations [35], these results can be considered as extreme for a river if we compare our results with those obtained by Vliet et al. [36] analyzing different rivers from Asia, Europe, and America. Using the PCA, we observed a positive relationship in the fourth component between water temperature and Fe. These results coincide with those obtained by other investigations [37] under laboratory conditions. In addition, some authors $[38,39]$ remarked that an increase in water temperature can represent a parallel increase in other heavy metals content such as $\mathrm{Zn}, \mathrm{Cu}$, and $\mathrm{Cd}$ or physicochemical properties such as $\mathrm{DO}$ and $\mathrm{pH}$.

These high polluted sampling points also coincide with another factor to be considered: the proximity to urban areas, including high industrialized cities such as Arys, Qyzylorda or Kentau, which are specialized in the petroleum industry. It is important to highlight that Kazakhstan is one of the most important producers of these combustibles. The industrialized areas need to develop a complex system of transport and infrastructures such as roads, railways, and ports, which, according to several authors, are one of the most importann sources of pollution related to $\mathrm{Pb}, \mathrm{Ni}, \mathrm{Cu}, \mathrm{Cd}$ and Co $[40,41]$. In addition, the increase in tourism should be considered in this area, because this area highly overlaps the Silk Road [42].

Another factor detected with a high correlation with the heavy metal content is COD, which other authors remarked that more attention must be paid if a linear correlation is found [43]. Some 
authors [44] stated that the intrusion of seawater can involve several changes in this parameter and, subsequently, in heavy metal adsorption. However, in the Syr Darya River, this possibility cannot be contemplated, unless this effect can be produced by intrusions of the Aral Sea [45] or the particle mobilization due to the wind effect [46]. Jensen et al. [47] highlighted that many populations are suffering from this polluted water due to the Soviet agriculture and industries [44,45]. Thus, we observed that the introduction of unplanned industrialization and agricultural plans is comprising water management and quality in this area, as also confirmed by Indoitu et al. [46].

Apart from the water sampling collected close to the Aral Sea and the urban areas, another hotspot along the Syr Darya River is located at Nos. 38-39 and 42-43. These territories contain pasture areas. As several authors highlighted that many animals along vast territories can generate a negative impact on water use management [47-49]. The water can be affected by erosion and sediment mobilization into rivers from urine and excrements dropped by the animals [50,51]. On the other hand, water contamination can also play a role in animal intoxication [52]. It is also important to remark on the possible influence of the natural sources of these heavy metal contents. Several authors highlighted that this possibility must be considered to make correct interpretations [53].

In the future, further research should be conducted to find the natural or anthropogenic sources of these heavy metals by using remote sensing data [54,55] or multivariate techniques [56]. To achieve this goal, a key question is also the connectivity processes, because heavy metal transport can be very different considering different slopes, soils, lithologies and vegetation cover [57]. In addition, it is interesting to consider the performing a temporal analysis of these changes, because climate variations and land use changes could rapidly modify these results [58,59].

In this research, we preferred the use of the HPI index because, as mentioned by several authors who have used it in Asian countries [27,44,60,61], it does not need specific water properties that other indexes such as Alberta's river water quality index require. In this first approach, our purpose was to highlight the important levels of heavy metal content in the river associated with other water properties. We assumed that the concept of water quality is much broader than the assessment of some heavy metals, $\mathrm{DO}, \mathrm{COD}$, temperature and organic matter during a water sampling campaign of four days, $25 \mathrm{~cm}$ depth and only under dry conditions. Thus, we considered the possibility that the use of a general water quality index could be a mistake and a too general assumption. The main goal of this research was to show the readers (scientific community, stakeholders and policymakers) a potential land degradation process associated to the above-mentioned specific moments (dry weather conditions, surface water and hotspots close to specific land uses). We demonstrate that a problem exists, which must be further investigated in the future: the increasing pollution due to anthropogenic and natural factors in the Syr Darya River in Kazakhstan.

\section{Conclusions}

After assessing the results, we can affirm that an important problem of heavy metal contents in some points along the border areas of the Syr Darya River exists. The main problems are related to the high content of $\mathrm{Fe}, \mathrm{Co}$, and $\mathrm{Ni}$, which were well-correlated with water temperature and COD. Moreover, the proximity to urban and industrialized areas, the high degraded Aral Sea and grazing areas possibly enhance the levels of pollution. In the future, considering the important role that agriculture and pasture play in the Kazakh economy, we insist upon the importance of applying water quality control measures. The current water conservation practices are inadequate along the Syr Darya River in Kazakhstan. Our recommendation for the readers and researchers who are planning their sampling campaign is that they have to increase the number of water samples and depths, and focus on specific land uses close to the most polluted areas. Moreover, new sampling campaigns should be devoted to monitoring all variables instead of only one variable correlate it to another because of the high variability of the results obtained. 
Author Contributions: Conceptualization, S.Y., R.K. and J.R.-C.; Methodology and validation, S.Y. and G.I.; Formal analysis, S.Y., L.M., A.S., G.I., Y.G., V.K., A.K., and J.R.-C.; Writing, S.Y., J.R.-C., R.K. and G.I.; Project administration, J.A.; and Funding acquisition, J.A.

Funding: This research was funded and supported by the National Natural Science Foundation of China (U1603242), the Training Program for Youth Innovative Talents in Science and Technology in Xinjiang (QN2016BS0052) and CAS "Light of West China" Program (2017-XBQNXZ-B-012).

Acknowledgments: Moreover, we would like to thank the guest editor, Manuel López-Vicente, and the anonymous reviewers for their appreciated work, helpful suggestions and corrections.

Conflicts of Interest: The authors declare no conflict of interest.

\section{References}

1. Ahearn, D.S.; Sheibley, R.W.; Dahlgren, R.A.; Anderson, M.; Johnson, J.; Tate, K.W. Land use and land cover influence on water quality in the last free-flowing river draining the western Sierra Nevada, California. J. Hydrol. 2005, 313, 234-247. [CrossRef]

2. Cosgrove, W.J.; Loucks, D.P. Water management: Current and future challenges and research directions. Water Resour. Res. 2015, 51, 4823-4839. [CrossRef]

3. Godheja, J.; Sk, S.; Siddiqui, S.A.; Dr, M. Xenobiotic compounds present in soil and water: A review on remediation strategies. J. Environ. Anal. Toxicol. 2016, 6, 1-18. [CrossRef]

4. Tepe, N.; Romero, M.; Bau, M. High-technology metals as emerging contaminants: Strong increase of anthropogenic gadolinium levels in tap water of Berlin, Germany, from 2009 to 2012. Appl. Geochem. 2014, 45, 191-197. [CrossRef]

5. Ríos, J.M.; Lana, N.B.; Ciocco, N.F.; Covaci, A.; Barrera-Oro, E.; Moreira, E.; Altamirano, J.C. Implications of biological factors on accumulation of persistent organic pollutants in Antarctic notothenioid fish. Ecotoxicol. Environ. Saf. 2017, 145, 630-639. [CrossRef] [PubMed]

6. Keesstra, S.; Geissen, V.; Mosse, K.; Piiranen, S.; Scudiero, E.; Leistra, M.; van Schaik, L. Soil as a filter for groundwater quality. Curr. Opin. Environ. Sustain. 2012, 4, 507-516. [CrossRef]

7. Bean, T.G.; Rattner, B.A.; Lazarus, R.S.; Day, D.D.; Burket, S.R.; Brooks, B.W.; Haddad, S.P.; Bowerman, W.W. Pharmaceuticals in water, fish and osprey nestlings in Delaware River and Bay. Environ. Pollut. 2018, 232, 533-545. [CrossRef] [PubMed]

8. Favas, P.J.C.; Pratas, J.; Rodrigues, N.; D'Souza, R.; Varun, M.; Paul, M.S. Metal(loid) accumulation in aquatic plants of a mining area: Potential for water quality biomonitoring and biogeochemical prospecting. Chemosphere 2018, 194, 158-170. [CrossRef] [PubMed]

9. Ponsadailakshmi, S.; Sankari, S.G.; Prasanna, S.M.; Madhurambal, G. Evaluation of water quality suitability for drinking using drinking water quality index in Nagapattinam district, Tamil Nadu in Southern India. Groundw. Sustain. Dev. 2018, 6, 43-49. [CrossRef]

10. Tao, Y.; Yu, J.; Liu, X.; Xue, B.; Wang, S. Factors affecting annual occurrence, bioaccumulation, and biomagnification of polycyclic aromatic hydrocarbons in plankton food webs of subtropical eutrophic lakes. Water Res. 2018, 132, 1-11. [CrossRef] [PubMed]

11. Romero-Romero, S.; Herrero, L.; Fernández, M.; Gómara, B.; Acuña, J.L. Biomagnification of persistent organic pollutants in a deep-sea, temperate food web. Sci. Total Environ. 2017, 605-606, 589-597. [CrossRef] [PubMed]

12. Cheng, Z.; Chen, L.-J.; Li, H.-H.; Lin, J.-Q.; Yang, Z.-B.; Yang, Y.-X.; Xu, X.-X.; Xian, J.-R.; Shao, J.-R.; Zhu, X.-M. Characteristics and health risk assessment of heavy metals exposure via household dust from urban area in Chengdu, China. Sci. Total Environ. 2018, 619-620, 621-629. [CrossRef] [PubMed]

13. Wijesiri, B.; Deilami, K.; McGree, J.; Goonetilleke, A. Use of surrogate indicators for the evaluation of potential health risks due to poor urban water quality: A Bayesian Network approach. Environ. Pollut. 2018, 233, 655-661. [CrossRef] [PubMed]

14. Mishra, B.K.; Regmi, R.K.; Masago, Y.; Fukushi, K.; Kumar, P.; Saraswat, C. Assessment of Bagmati river pollution in Kathmandu Valley: Scenario-based modeling and analysis for sustainable urban development. Sustain. Water Qual. Ecol. 2017, 9-10, 67-77. [CrossRef]

15. Abdollahi, Z.; Kavian, A.; Sadeghi, S.H.R. Spatio-temporal changes of water quality variables in a highly disturbed river. Glob. J. Environ. Sci. Manag. 2017, 3, 243-256. [CrossRef] 
16. Angrill, S.; Petit-Boix, A.; Morales-Pinzón, T.; Josa, A.; Rieradevall, J.; Gabarrell, X. Urban rainwater runoff quantity and quality-A potential endogenous resource in cities? J. Environ. Manag. 2017, 189, 14-21. [CrossRef] [PubMed]

17. Miller, J.D.; Hutchins, M. The impacts of urbanisation and climate change on urban flooding and urban water quality: A review of the evidence concerning the United Kingdom. J. Hydrol. Reg. Stud. 2017, 12, 345-362. [CrossRef]

18. Kazhydromet (Казгидромет). Available online: https://kazhydromet.kz/kk (accessed on 3 September 2018).

19. Ilyas, T. The Syr Darya River-New ecological disaster in Central Asia. Acta Sci. Pol. Hortorum Cultus 2015, 14, 135-140. [CrossRef]

20. Wegerich, K.; Van Rooijen, D.; Soliev, I.; Mukhamedova, N.; Wegerich, K.; Van Rooijen, D.; Soliev, I.; Mukhamedova, N. Water security in the Syr Darya Basin. Water 2015, 7, 4657-4684. [CrossRef]

21. Bekturganov, Z.; Tussupova, K.; Berndtsson, R.; Sharapatova, N.; Aryngazin, K.; Zhanasova, M.; Bekturganov, Z.; Tussupova, K.; Berndtsson, R.; Sharapatova, N.; et al. Water related health problems in Central Asia-A review. Water 2016, 8, 219. [CrossRef]

22. Dukhovny, V.; Litvak, L. Effect of irrigation on Syr Darya water regime and water quality. In Arid Land Irrigation in Developing Countries; Worthington, E.B., Ed.; Elsevier Ltd.: Pergamon, Turkey, 1977; pp. 265-275. ISBN 978-0-08-021588-4.

23. Soliev, I.; Wegerich, K.; Kazbekov, J.; Soliev, I.; Wegerich, K.; Kazbekov, J. The costs of benefit sharing: Historical and institutional analysis of shared water development in the Ferghana Valley, the Syr Darya Basin. Water 2015, 7, 2728-2752. [CrossRef]

24. Sorg, A.; Mosello, B.; Shalpykova, G.; Allan, A.; Hill Clarvis, M.; Stoffel, M. Coping with changing water resources: The case of the Syr Darya river basin in Central Asia. Environ. Sci. Policy 2014, 43, 68-77. [CrossRef]

25. Popov, Y.M.; Pavlichenko, L.M.; Bogachev, V.P. Investigation of river pollution Syr Darya for the construction of a comprehensive water quality assessment. Hydrometeorol. Ecol. 1996, 2, 207-223.

26. Carral, E.; Villares, R.; Puente, X.; Carballeira, A. Influence of watershed lithology on heavy metal levels in estuarine sediments and organisms in Galicia (North-West Spain). Mar. Pollut. Bull. 1995, 30, 604-608. [CrossRef]

27. Conversi, A.; McGowan, J.A. Variability of water column transparency, volume flow and suspended solids near San Diego sewage outfall (California): 15 years of data. Chem. Ecol. 1992, 6, 133-147. [CrossRef]

28. Shrestha, N.K.; Leta, O.T.; Bauwens, W. Development of RWQM1-based integrated water quality model in OpenMI with application to the River Zenne, Belgium. Hydrol. Sci. J. 2017, 62, 774-799. [CrossRef]

29. Van Griensven, A.; Vandenberghe, V.; Bols, J.; De Pauw, N.; Goethals, P.; Meirlaen, J.; Vanrolleghem, P.A.; Van Vooren, L.; Bauwens, W. Experience and organisation of automated measuring stations for river water quality monitoring. In Proceedings of the 1st World Congress of the International Water Association, Paris, France, 3-7 July 2000.

30. Abou Zakhem, B.; Hafez, R. Heavy metal pollution index for groundwater quality assessment in Damascus Oasis, Syria. Environ. Earth Sci 2015, 73, 6591-6600. [CrossRef]

31. Reza, R.; Singh, G. Heavy metal contamination and its indexing approach for river water. Int. J. Environ. Sci. Technol. 2010, 7, 785-792. [CrossRef]

32. WHO. Guidelines for Drinkingwater Quality; World Health Organisation: Geneva, Switzerland, 2011 ; p. 564.

33. Arable Land (Hectares per Person) Data. Available online: https://data.worldbank.org/indicator/AG.LND. ARBL.HA.PC (accessed on 14 September 2018).

34. Żelazny, M.; Rajwa-Kuligiewicz, A.; Bojarczuk, A.; Pęksa, Ł. Water temperature fluctuation patterns in surface waters of the Tatra Mts., Poland. J. Hydrol. 2018, 564, 824-835. [CrossRef]

35. Ouellet-Proulx, S.; Chimi Chiadjeu, O.; Boucher, M.-A.; St-Hilaire, A. Assimilation of water temperature and discharge data for ensemble water temperature forecasting. J. Hydrol. 2017, 554, 342-359. [CrossRef]

36. Vliet, M.T.H.; van Ludwig, F.; Zwolsman, J.J.G.; Weedon, G.P.; Kabat, P. Global river temperatures and sensitivity to atmospheric warming and changes in river flow. Water Resour. Res. 2011, 47. [CrossRef]

37. Pierre, S.; Tarnowska, K.; Hachfi, L.; Coupé, S.; Simide, R.; Couvray, S.; Garnier, C.; Grimaldi, M.; Richard, S.; Gaillard, S. Effects of water temperature increase and heavy metals contamination on WAP65 gene expression in sea bass (Dicentrarchus labrax) liver. Cell. Mol. Biol. 2011, 57, 1614-1622. 
38. Li, H.; Shi, A.; Li, M.; Zhang, X. Effect of pH, Temperature, Dissolved Oxygen, and Flow Rate of Overlying Water on Heavy Metals Release from Storm Sewer Sediments. Available online: https:/ /www.hindawi.com/ journals/jchem/2013/434012/ (accessed on 14 September 2018).

39. Fritioff, A.; Kautsky, L.; Greger, M. Influence of temperature and salinity on heavy metal uptake by submersed plants. Environ. Pollut. 2005, 133, 265-274. [CrossRef] [PubMed]

40. Andersson, J.; Oudin, A.; Sundström, A.; Forsberg, B.; Adolfsson, R.; Nordin, M. Road traffic noise, air pollution, and risk of dementia-Results from the Betula project. Environ. Res. 2018, 166, 334-339. [CrossRef] [PubMed]

41. Ermolin, M.S.; Fedotov, P.S.; Ivaneev, A.I.; Karandashev, V.K.; Fedyunina, N.N.; Burmistrov, A.A. A contribution of nanoscale particles of road-deposited sediments to the pollution of urban runoff by heavy metals. Chemosphere 2018, 210, 65-75. [CrossRef] [PubMed]

42. Kudaibergenova, D.T. "My Silk Road to You": Re-imagining routes, roads, and geography in contemporary art of "Central Asia". J. Eurasian Stud. 2017, 8, 31-43. [CrossRef]

43. Costa, S.P.F.; Pereira, S.A.P.; Pinto, P.C.A.G.; Araujo, A.R.T.S.; Passos, M.L.C.; Saraiva, M.L.M.F.S. Environmental impact of ionic liquids: Automated evaluation of the chemical oxygen demand of photochemically degraded compounds. Chemphyschem 2017, 18, 1351-1357. [CrossRef] [PubMed]

44. Van den Brand, T.P.H.; Roest, K.; Chen, G.-H.; Brdjanovic, D.; van Loosdrecht, M.C.M. Effects of chemical oxygen demand, nutrients and salinity on sulfate-reducing bacteria. Environ. Eng. Sci. 2015, 32, 858-864. [CrossRef]

45. Erdinger, L.; Hollert, H.; Eckl, P. Aral Sea: An ecological disaster zone with impact on human health. In Encyclopedia of Environmental Health; Nriagu, J.O., Ed.; Elsevier: Burlington, ON, Canada, 2011; pp. 136-144. ISBN 978-0-444-52272-6.

46. Indoitu, R.; Kozhoridze, G.; Batyrbaeva, M.; Vitkovskaya, I.; Orlovsky, N.; Blumberg, D.; Orlovsky, L. Dust emission and environmental changes in the dried bottom of the Aral Sea. Aeolian Res. 2015, 17, 101-115. [CrossRef]

47. Jensen, S.; Mazhitova, Z.; Zetterström, R. Environmental pollution and child health in the Aral Sea region in Kazakhstan. Sci. Total Environ. 1997, 206, 187-193. [CrossRef]

48. McDermid, S.S.; Winter, J. Anthropogenic forcings on the climate of the Aral Sea: A regional modeling perspective. Anthropocene 2017, 20, 48-60. [CrossRef]

49. Lathuillière, M.; Coe, M.; Castanho, A.; Graesser, J.; Johnson, M.; Lathuillière, M.J.; Coe, M.T.; Castanho, A.; Graesser, J.; Johnson, M.S. Evaluating water use for agricultural intensification in southern Amazonia using the water footprint sustainability assessment. Water 2018, 10, 349. [CrossRef]

50. Pulido, M.; Barrena-González, J.; Badgery, W.; Rodrigo-Comino, J.; Cerdà, A. Sustainable grazing. Curr. Opin. Environ. Sci. Health 2018, 5, 42-46. [CrossRef]

51. Nicu, I.; Nicu, I.C. Is overgrazing really influencing soil erosion? Water 2018, 10, 1077. [CrossRef]

52. Rakkar, M.K.; Blanco-Canqui, H.; Drijber, R.A.; Drewnoski, M.E.; MacDonald, J.C.; Klopfenstein, T. Impacts of cattle grazing of corn residues on soil properties after 16 years. Soil Sci. Soc. Am. J. 2017, 81, 414-424. [CrossRef]

53. Roche, L.M.; Kromschroeder, L.; Atwill, E.R.; Dahlgren, R.A.; Tate, K.W. Water quality conditions associated with cattle grazing and recreation on national forest lands. PLoS ONE 2013, 8, e68127. [CrossRef] [PubMed]

54. Hubbard, R.K.; Newton, G.L.; Hill, G.M. Water quality and the grazing animal. J. Anim. Sci. 2004, 82 E-Suppl, E255-E263. [CrossRef]

55. Gholizadeh, M.H.; Melesse, A.M.; Reddi, L. A comprehensive review on water quality parameters estimation using remote sensing techniques. Sensors 2016, 16, 1298. [CrossRef] [PubMed]

56. Populus, J.; Hastuti, W.; Martin, J.-L.M.; Guelorget, O.; Sumartono, B.; Wibowo, A. Remote sensing as a tool for diagnosis of water quality in Indonesian seas. Ocean Coast. Manag. 1995, 27, 197-215. [CrossRef]

57. Basatnia, N.; Hossein, S.A.; Rodrigo-Comino, J.; Khaledian, Y.; Brevik, E.C.; Aitkenhead-Peterson, J.; Natesan, U. Assessment of temporal and spatial water quality in international Gomishan Lagoon, Iran, using multivariate analysis. Environ. Monit Assess 2018, 190, 314. [CrossRef] [PubMed]

58. Turnbull, L.; Hütt, M.-T.; Ioannides, A.A.; Kininmonth, S.; Poeppl, R.; Tockner, K.; Bracken, L.J.; Keesstra, S.; Liu, L.; Masselink, R.; et al. Connectivity and complex systems: Learning from a multi-disciplinary perspective. Appl. Netw. Sci. 2018, 3, 11. [CrossRef] 
59. Calijuri, M.L.; Castro, J.d.S.; Costa, L.S.; Assemany, P.P.; Alves, J.E.M. Impact of land use/land cover changes on water quality and hydrological behavior of an agricultural subwatershed. Environ. Earth Sci 2015, 74, 5373-5382. [CrossRef]

60. Huang, J.; Zhan, J.; Yan, H.; Wu, F.; Deng, X. Evaluation of the Impacts of Land Use on Water Quality: A Case Study in The Chaohu Lake Basin. Available online: https: / www.hindawi.com/journals/tswj/2013/329187/ (accessed on 14 September 2018).

61. Kumar, V.; Sharma, A.; Kumar, R.; Bhardwaj, R.; Thukral, A.K.; Rodrigo-Comino, J. Assessment of heavy-metal pollution in three different Indian water bodies by combination of multivariate analysis and water pollution indices. Hum. Ecol. Risk Assess Int. J. 2018, 1-16. [CrossRef]

2018 by the authors. Licensee MDPI, Basel, Switzerland. This article is an open access article distributed under the terms and conditions of the Creative Commons Attribution (CC BY) license (http://creativecommons.org/licenses/by/4.0/). 